\title{
Saccoglossa (Opisthobranchia) from the Ryukyu Islands
}

$\operatorname{AUTHOR}(S)$ :

Ichikawa, Marina

\section{CITATION:}

Ichikawa, Marina. Saccoglossa (Opisthobranchia) from the Ryukyu Islands. PUBLICATIONS OF THE SETO MARINE BIOLOGICAL

LABORATORY 1993, 36(3): 119-139

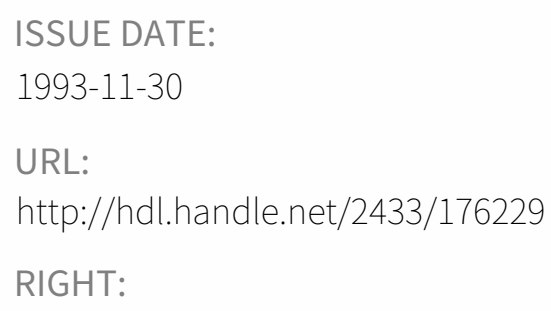




\title{
Saccoglossa (Opisthobranchia) from the Ryukyu Islands
}

\author{
Marina IchiKawa \\ Institute of Zoology, University of Vienna, \\ Althanstrasse 14, A-1090 Vienna, Austria \\ With Text-figures $1-12$ and Plates $I-I I$
}

\begin{abstract}
Saccoglossans collected in the central and southern Ryukyu Islands are described. Of 21 species recorded, 11 species are described as new: Valvatella angeliniana, Aplysiopsis wrangeliae, Costasiella pazeli, C. usagi, C. vegae, C. rubrolineata, C. iridophora, C. kuroshimae, Elysiobranchus ryukyuensis, Elysia flavipunctata, and E. minima.
\end{abstract}

Key words: Gastropoda, Opisthobranchia, Saccoglossa, Ryukyu Islands

\section{Introduction}

The order Saccoglossa von Ihering, 1876 (=Ascoglossa Bergh, 1876; = Monostichoglossa Pagenstecher, 1875) comprises opisthobranch gastropods that, with a few exceptions, feed on algae. They are distinguished by their specialized alimentary system. The radula has a series of single rows of teeth and used teeth are deposited in a ventroterminal sac. The buccal apparatus is specially adapted to a sucking mode of feeding. Saccoglossans are equipped with one pair of rhinophores, are univalved, bivalved or shell-less, and occur widely except for polar regions.

Until now 16 species of Saccoglossa have been recorded from the Ryukyu Islands of southwestern Japan:

Tamanovalva limax Kawaguti, 1959: Kitao (1976)

Tamanovalva sp. (= Tamanovalva limax): Kitao (1976)

Julia japonica Kuroda \& Habe, 1951: Kitao (1976, 1978)

J. mishimaensis Kawaguti \& Yamasu, 1982 (q.v.)

J. zebra Kawaguti, 1981 (q.v.)

Volvatella viridis Hamatani, 1976: Kitao (1976)

Oxynoe viridis (Pease, 1861): Kitao (1976), Hamatani (1980)

Lobiger souverbii Fischer, 1856: Kitao (1977)

Elysia ornata (Swainson, 1840): Kitao (1977)

E. splendens Baba, 1949: Kitao (1977)

E. tokarensis Baba, 1957: Kitao (1977)

E. babai Prouvot-Fol, 1946 (=E. viridis Baba, 1936)

E. yaeyamana Baba, 1936 (q.v.)

Plakobranchus ocellatus Van Hasselt, 1925: Baba (1936)

Cyerce nigricans (Pease, 1866): Baba (1936)

Publ. Seto Mar. Biol. Lab., 36(3/4), 119-139, 1993. 


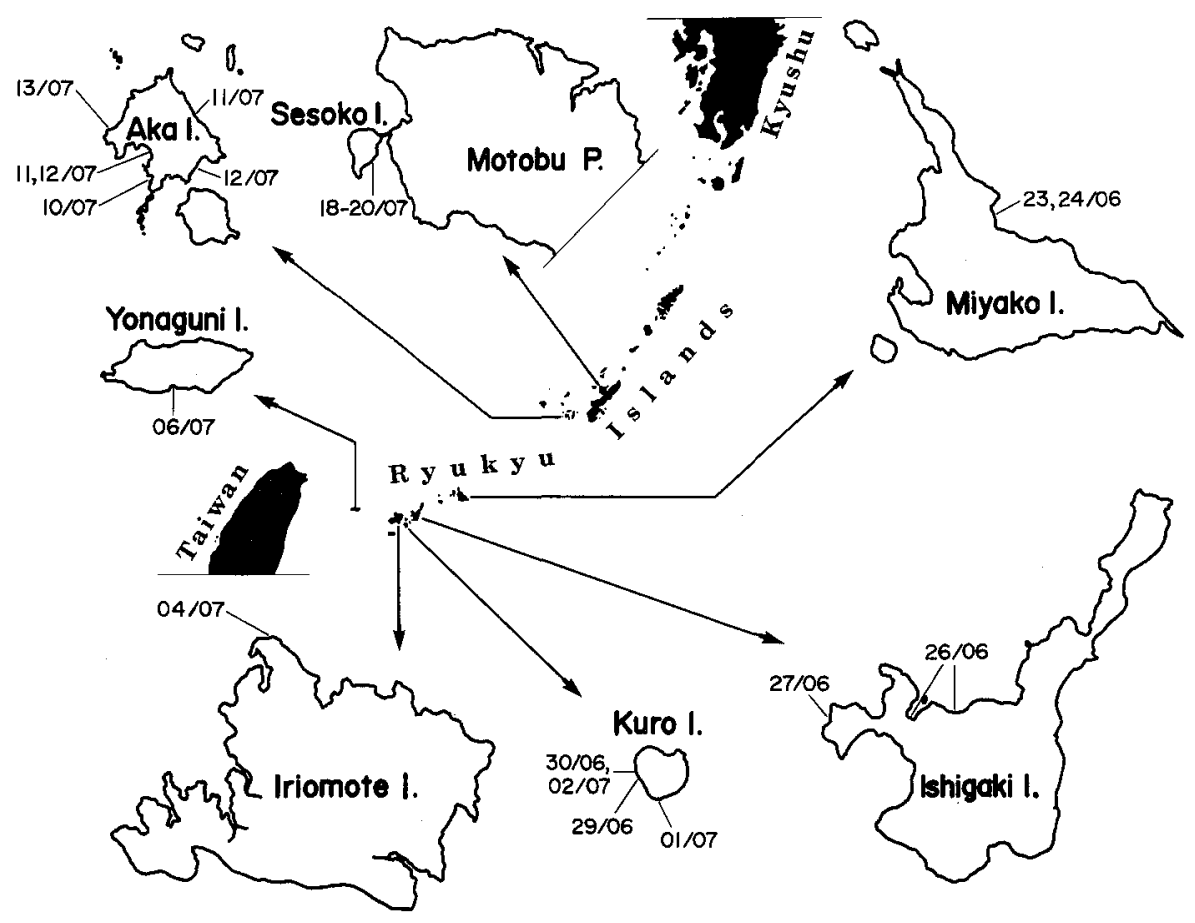

Fig. 1. Map showing the Ryukyu Islands and the localities of collection indicated by dates.

Ercolania smaragdina (Baba, 1949): Toma (1990)

The present paper gives an account of a collection of saccoglossans from the Ryukyu Islands. The collection was made on coral reefs and in shallow waters around the islands of Okinawa, Sesoko, Aka, Miyako, Ishigaki, Kuro, Iriomote and Yonaguni during the months of June and July, 1991. Most of the species collected were found on various green algae between patches of reef coral, between seagrass beds and on sandy beaches. Only the descriptions of external morphology are presented herein. Detailed anatomical studies of the new species will be presented in the subsequent papers.

\section{Materials and Methods}

All specimens were collected by snorkeling. Locations and approximate depths are mentioned for the individual species (Fig. 1). The animals were photographed either through a Canon camera equipped with a $55 \mathrm{~mm}$ macro-lens or through a camera-equipped dissecting microscope if available, drawn alive, relaxed in $3.6 \% \mathrm{MgCl}_{2}$ solution in seawater and fixed in Bouin's solution for later histological study. All holotypes were sectioned because of the better durability of such preparations; a long specimen life is not guaranteed by keeping them in alcohol: The holotype slides will be deposited in the Naturhistorisches Museum in Vienna, Austria (NHMW); all the other specimens of the new species are paratypes, which will be depositied in the collection of the Seto Marine Biological Laboratory (SMBL) and in the author's 
collection.

\author{
Systematic Account \\ Family Volvatellidae \\ Genus Volvatella Pease, 1860 \\ Volvatella viridis Hamatani, 1976
}

(Plate I, fig. 1)

Material examined: Kuro Island, vicinity of Kuroshima Marinc Center, on Caulerpa racemosa var, occidentalis Borgesen, 30/06/1991, 1 specimen; Aka Island, Kushibaru, on Caulerpa serrulata var. serrulata f. lata Weber van Bosse, 13/07/1991, 1 specimen.

Description:

The maximum length of the specimens is $12 \mathrm{~mm}$. The soft body is milky white and is covered with opaque spots. The anterior corners of the head protrude and bear a pair of short rhinophores. The foot is broad, the anterior foot-corners being wider than the posterior ones. The eyes are situated in deep grooves on the sides of the head. The shell aperture occupies more than half of the shell length. The posterior part of the shell, the spout, is short and situated to the right of the median line. Due to green pigment in the mantle tissue the transparent shell appears green.

\title{
Volvatella angeliniana sp. nov.
}

(Fig. 2; Plate I, figs. $2 \& 3$ )

Material examined: Sesoko Island, vicinity of Sesoko Marine Science Center, 2-3m deep, on Caulerpa racemosa var. clavifera f. macrophysa Weber van Bosse, 18/06/1991, 1 specimen.

Holotype: body length $25 \mathrm{~mm}$, collected as above, NHMW 85994.

Description:

Holotype.

The softt body is creamy white and is covered with many tiny white spots, and can be withdrawn completely into the shell. The anterior corners of the head are extended into labial tentacles, bearing on their dorsal sides a pair of short, bright orange rhinophores. Eyes are clearly seen behind the bases of the rhinophores. The foot is very short and triangular, not extending posteriorly beyond the aperture of the shell; its anterior part is wide with rounded corners; posteriorly it ends in a narrow, rounded tail. The ovoid shell, $2 \mathrm{~mm}$ long, has two orange bands, one on its anterior margin and the other on its spout; the rest of the shell is furnished with round white spots and otherwise appears to be of the same milky white colour as the soft body due to the underlying mantle.

Remarks:

Without better knowledge of the previously described species of Volvatella, it is 

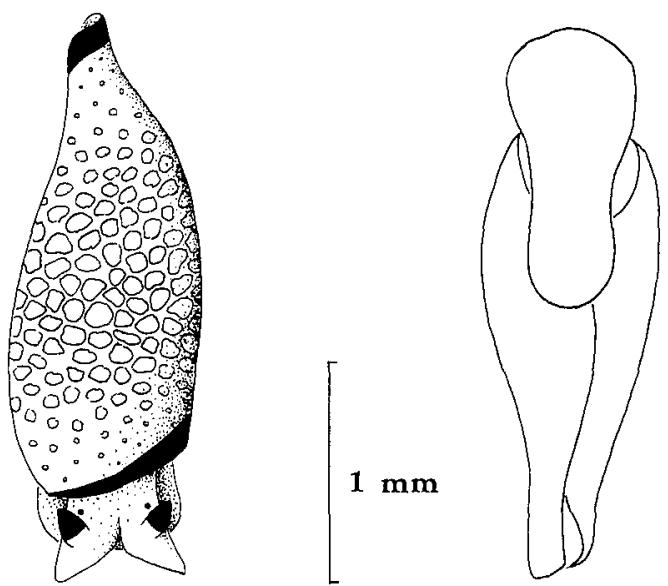

Fig. 2. Volvatella angeliniana sp. nov. Left: dorsal view. Right: ventral view.

difficult to select definite characters that are specific to this new species. The body colouration resembles that described for $V$. ficula Burn, 1966, but in the latter the rhinophores are white and no round white spots cover the shell.

The present species is distinguished from V. (=Arthessa) evansi Kay, 1961, by the position of the eyes, the shape of the shell and the head, and the colour pattern. The position of the eyes is the same as described for specimens of Volvatella by Baba (1966), but, unlike Baba's species, the eyes are visible from the surface, as in $V$. ayakii Hamatani, 1972. Differences from $V$. ayakii are the more slender shell and the longer spout in the species; moreover, the orange bands of the shell of the present species were not recognized in $V$. ayakii. Clark (1982) remarked that orange or red "shell" mantle colours are supposedly due to carotenoid pigments and "as these are often of dietary origin, their presence or absence is dubious utility as a diagnostic feature. Nonetheless, because of the colour of the rhinophores and the spots and shape of the comparatively long, ovoid shell with a long spout, the present species is regarded as a separate species. Further anatomical investigation and comparisons are needed in this genus.

The new species is just named after the first impression.

\section{Volvatella sp.}

(Plate I, fig. 4)

Material examined: Kuro Island, Nakamoto Beach, on Caulerpa racemosa var. occidentalis and Caulerpa serrulata var. serrulata f. late, 29/06/1991, 6 specimens; Kuro Island, southwest coast, on Caulerpa serrulata, 01/07/1991, 1 specimen; Aka Island, on Caulerpa serrulata, 10/07/1991, 1 specimen; Aka Island, Agonohama, on Caulerpa racemosa, 11/07/1991, 1 specimen; Aka Island, Kushibaru, on Caulerpa serrulata, 13/07/1991, 1 specimen.

Description: 
The specimens of this species are similar to $V$. viridis, except that the shell appears yellowish-white due to the mantle colour and is more slender with a longer spout than that of $V$. viridis.

Remarks:

The specimens may be attributable to either $V$. kawamurai Habe, 1949 or $V$. ayakii Hamatani, 1972. The ratio of the aperture and shell length is more like that of $V$. ayakii. The radula is reported to be different between $V$. kawamurai and $V$. ayakii, but it is questionable that this is their only difference. The radula of the present species has not been examined, so these species can not be compared on this feature. The present species may also be conspecific with Kitao's (1976) V. sp. from Ishigaki Island.

All the specimens were found among algal thalli.

Genus Ascobulla Marcus, 1972

\title{
Ascobulla japonica (Hamatani, 1969)
}

\author{
(Plate I, fig. 5)
}

Material examined: Kuro Island, near Kuroshima Marine Center, on Caulerpa racemosa var. occidentalis, $02 / 07 / 1991,2$ specimens.

Description:

Both specimens measured about $5 \mathrm{~mm}$ in length when extended, and the soft body could be completely retracted into the shell. The head is divided into two head-shields which meet anteriorly. Posteriorly the head-shields are farther apart, as described by Hamatani (1969). Between the head-shields and the shell is a distinct, long neck. The foot is small with rounded ends. Opaque white spots are scattered all over the white body. Eyes could not be seen through the dorsal surface. The cylindrical shell is colourless but appears yellowish due to the colour of visceral organs shining through and is finely striated longitudinally at the posterior end.

\author{
Family Lobigeridae \\ Genus Lobiger Krohn, 1847
}

\section{Lobiger souverbii Fischer, 1856}

(Plate I, figs. $6 \& 7$ )

Material examined: Aka Island, Agonohama, on Caulerpa serrulata var. serrulata f. lata, 11/07/1991, 2 specimens.

Description:

One specimen measured $1 \mathrm{~cm}$ in length, and the other $3 \mathrm{~cm}$. The four parapodia vary in size; they are indented and form leave-like lobes. The general colour of the soft body is green. The parapodial lobes are dorsally enrolled towards the median 
line. The margins of the parapodia are red or dotted red. The papillae covering the enrolled rhinophores, the parapodia and the sides of the foot are white with minute green dots. Beneath the transparent shell the mantle is yellowish-green with three conspicuous long and several short blue lines on the dorsal surface. In the smaller specimen, the parapodia are just slightly enrolled with no red areas, and no papillae are present on any part of the soft body.

\section{Family Oxynoidae \\ Genus Oxynoe Rafinesque, 1819 \\ Oxynoe viridis (Pease), 1861}

(Plate I, figs. 8a-c, Plate II, fig. 8d)

Material examined: Kuro Island, Nakamoto Beach, on Caulerpa serrulata var. serrulata f. lata, 29/06/1991, 12 specimens (1); Kuro Island, near Kuroshima Marine Center, on Caulerpa racemosa var. occidentalis and Caulerpa lentillifera, 30/06/1991, 4 specimens (2); Aka Island, Agonohama, on Caulerpa serrulata or Caulerpa racemosa, 10/07/1991, 2 specimens (3); Aka Island, Majanohama, on Caulerpa serrulata, $12 / 07 / 1991,2$ specimens (4).

\section{Description:}

Specimens collected at different sites differed from each other in the pattern of body colouration.

The specimens from Nakamoto Beach (1) measured up to $25 \mathrm{~mm}$ long. The soft body is generally grass-green, and the rhinophores are furnished with 3 white stripes. The parapodia and the tail bear pointed, unpigmented papillae and are dotted with small dark spots. Along the parapodial margins and on the shell area, a few bigger, blue dots are present. White spots are scattered over the anterior part of the head and the tail. The specimens from near the Kuroshima Marine Center (2) were up to $4 \mathrm{~mm}$ long. Two dark spots are present on the dorsal side of each rhinophore, and small, dark dots on the parapodia. No papillae and no blue spots are present. The specimens from Agonohama (3), measuring $7 \mathrm{~mm}$ in length, are entirely green over the soft body, except for small, dark dots near the parapodial rim. In one of the specimens from Majanohama (4), $35 \mathrm{~mm}$ in length, the dorsal parts of the rhinophores are white, and on the inner side of the base of each rhinophore are two long, blue dots. Many blue spots are also scattered over the parapodia, the shell area and the tail. The parapodial margins are white. The other specimen from Majanohama, $5 \mathrm{~mm}$ in length, has blue spots on the rhinophores and parapodia. Black dots are limited to the parapodia. A few pointed papillae are present.

Remarks:

According to Hamatani (1980), the colour pattern may vary. He classified his specimens into three types according to the expression of the blue spots, which may be replaced by brownish spots or may disappear completely. Until further anatomical study of the present specimens is carried out, they are regarded as different 
colouration types.

\author{
Family Tamanovalvidae \\ Genus Tamanovalva Kawaguti \& Baba, 1959 \\ Tamanovalva limax Kawaguti \& Baba, 1959
}

(Plate II, fig. 9)

Material examined: Kuro Island, Nakamoto Beach, from Caulerpa serrulata var. serrulata f. lata, 29/06/1991, 1 specimen; Aka Island, from Caulerpa serrulata or C. racemosa, 10/07/1991, I specimen.

Remarks:

The specimen from Kuro Island measured $4 \mathrm{~mm}$ in length, and that from Aka Island $5 \mathrm{~mm}$.

Family Stiligeridae

Genus Hermaea Lovén, 1844

\title{
Hermaea dendritica (Alder \& Hancock, 1843)
}

(Plate II, fig. 10)

Material examined: Kuro Island, vicinity of Kuroshima Marine Center, on Caulerpa lentillifera, 30/06/1991, 1 specimen.

Remarks:

The specimen measured $7 \mathrm{~mm}$ in length.

$$
\begin{gathered}
\text { Genus Aplysiopsis Deshayes, } 1835 \\
\text { =Hermaeina Trinchese, } 1873
\end{gathered}
$$

\section{Aplysiopsis zerangeliae sp. nov.}

(Fig. 3; Plate II, fig. 11)

Material examined: Kuro Island, at 1-2 m depth, on Wrangelia tayloriana Tseng, 30/06 \& 02/07/1991, 6 specimens.

Holotype: body length $10 \mathrm{~mm}$, collected at Kuro Island, 02/07/1991, sectioned and mounted on 6 slides, NHMW 85995.

Paratype: all other specimens, deposited at Seto Marine Biological Laborotory and in the author's collection.

Description:

Holotype.

The body is transparent. The rhinophores are auriculate, with their anterior margin extended to form a ventral lobe that extends beyond the posterior margin. No oral tentacles are present. The indented cerata are arranged in about 12 rows. They contain branches of the liver diverticula, and therefore the cerata appear green or 


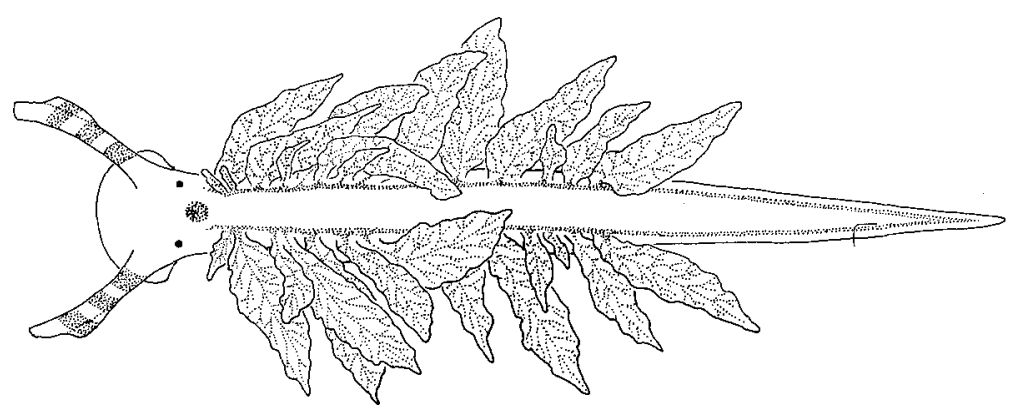

Fig. 3. Aplysiopsis terangeliae sp. nov. Dorsal view.

brownish. The rhinophores have three green horizontal stripes and the head is covered with minute white dots. Behind the eyes, in the middle of the neck, a dark spot is present. The border of the ventral side of the foot is marked by a dotted white line.

Paratype.

Some of the paratype specimens have two light brown, longitudinal stripes on the sole of the foot, as in other species of Aplysiopsis.

Remarks:

Until now, four species of Aplysiopsis (= Hermaeina) have been described from Japan:

Hermaeina orientalis Baba, 1949

Hermaeina nigra Baba, 1949

Hermaeina toyamana Baba, 1959

Hermaeina minor Baba, 1959

The present species differs from all these species in the shape and number of cerata, size and colour pattern. In $H$. nigra, the body is much longer, the branchial papillae are arranged in about 25 rows and the sole is uniformly dark. H. toyamana differs in its yellowish-white body colour. In $H$. toyamana and $H$. orientalis, a median brown or black band runs along the dorsal side of the head; this is missing in the present species. H. minor is completely black and the eyes are embedded in conspicuous white patches.

The occurrence of this new species is limited to the alga Wrangelia tayloriana, after which it is named. Its body shape and colour perfectly match this host.

Genus Ercolania Trinchese, 1872

\section{Ercolania smaragdina Baba, 1949}

(Plate II, fig. 12)

Material examined: Kuro Island, near Kuroshima Marine Center, on Caulerpa lentillifera, 30/06/1991, 3 specimens. 
Description:

The longest specimen measured $2 \mathrm{~cm}$. In contrast to Baba's original description, oral tentacles are present. The general body colour is green, the same colour as the alga the specimens were found on; the body shape exactly resembles the shape of a branch of the alga. The cerata are arranged in about 10 rows; they are conical, vary in size, and end in white, pointed tips. The distal extremities of the rhinophores are white, and white marks can also be found on the inner side of their bases. Immediately behind the eyes a conspicuous dark line crosses the neck. The posterior part of the foot, the tail, is green and is bordered by a white line.

Remarks:

The specimens indentified by Toma (1990) as Cyerce sp. certainly belong to Ercolania smaragdina, judging from the shape of rhinophores and cerata.

Family Costasiellidae Clark, 1984

Genus Costasiella Prouvot-Fol, 1951

Remarks:

The characteristics of the genus are auriculate or digitiform rhinophores, fusiform, non-flattened cerata and large, admedian eyes. Their digestive diverticula reach into the cerata. Clark (1984) established the family Costasiellidae because the genus Costasiella "is transitional in characteristics between Stiligeridae and Caliphyllidae, but differs in most characteristics from the other transitional hermaeid genera Hermaea and Aplysiopsis".

The number of rows of cerata varied in almost all the species of Costasiella studied herein. At the slightest manipulation, the animals autotomized their cerata. In all the herein described species, a large number of densely packed, inflated cerata in irregular rows are present, giving the impression that they cover the whole dorsal body. The innermost cerata are the largest. All animals were collected crawling on the alga Avrainvillea.

\section{Costasiella pazueli sp. nov.}

(Fig. 4; Plate II, fig. 13)

Matcrial examined: Miyako Island, Oura Beach, 0.5-1 m deep, on Avrainillea erecta A. \& E.S. Gepp, $23 \& 24 / 06 / 1991,6$ specimens.

Holotype: body length $5 \mathrm{~mm}$, collected on $24 / 06 / 1991$, sectioned and mounted on 7 slides, NHMW 85996.

Paratype: all the other 5 specimens, deposited at the Seto Marine Biological Laboratory and in the author's collection.

Description:

Holotype.

The large, contiguous eyes are situated between the long, simple rhinophores. 


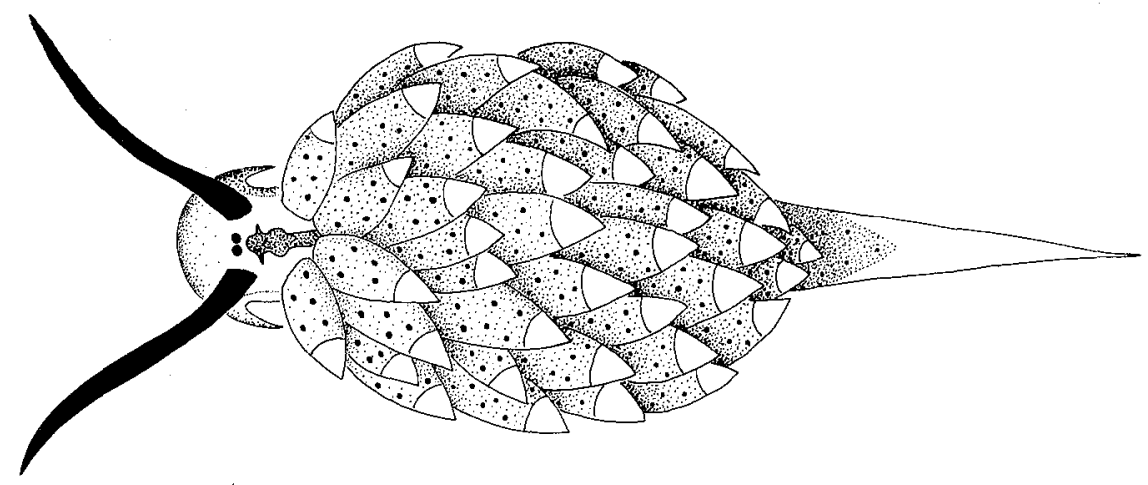

Fig. 4. Costasiella paweli sp. nov. Dorsal view.

Many inflated cerata are arranged in about 10 dense rows, and the pointed tail protrudes behind the cerata. The anterior corners of the foot are produced into long tentacles. The colour of the head and the tail is white, and the rhinophores are black or dark blue. A distinctive dark mark is located behind the eyes; the anterior part of the mark is somewhat star-shaped and its posterior part is elongated. The anterior margin of the foot and the area dorsal to the mouth are darkly pigmented. The cerata are green with white tips and are spotted with small, black chromatophores.

Paratype.

The body length ranged from 3 to $7 \mathrm{~mm}$.

Remarks:

The present species differs from C. formicaria (Baba, 1959), which is the only species of Costasiella described in Japan until now, in size, colour and number of rows of cerata. It is distinguished from C. ocellifera Simroth, 1895 (=C. lilianae Marcus \& Marcus, 1969; Thompson, 1977; Clark, 1984), C. nonatoi Marcus \& Marcus, 1960, C. illa Marcus, 1965 and $C$. pallida Jensen, 1983 in colour and the presence of tentaculiform anterior corners of the foot.

The species is named after my colleague Pawel Slawatycki, who found the first specimen.

\section{Costasiella usagi sp. nov.}

(Fig. 5; Plate II, fig. 14)

Material examined: Ishigaki Island, between Uganzaki and Yarabuzaki, 0.5-1 $\mathrm{m}$ deep, on Avrainvillea erecta, 27/06/1991, 5 specimens.

Holotype: body length $10 \mathrm{~mm}$, sectioned and mounted on 6 slides, NHMW 85997.

Paratype: the remaining 4 specimens, deposited at the Seto Marine Biological Laboratory and in the author's collection. 


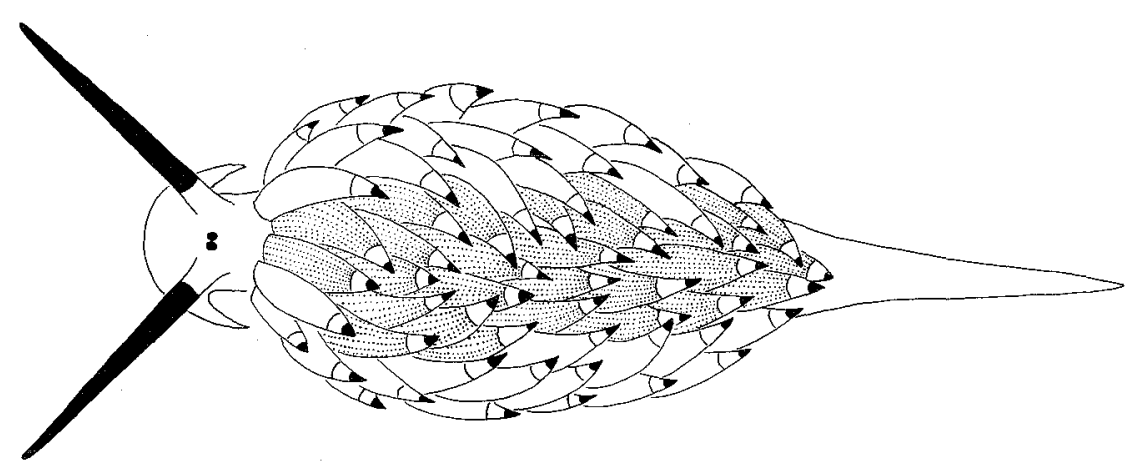

Fig. 5. Costasiella usagi sp. nov. Dorsal view.

\section{Description:}

Holotype.

The large eyes lie close together between the bases of the simple rhinophores. The anterior corners of the foot are tentaculiform and the tail is long and pointed. The head and the tail are not pimented, and the rhinophores are black. The median cerata are grey, while the outer ones are black. All the cerata possess a white end with a black tip. Moreover, all the cerata bear longitudinal striations reaching from the base of each ceras to the white apical portion. The cerata are arranged in about 10 rows. The ventral side of the foot is white.

Paratype.

Smaller specimens have the median cerata coloured green, instead of grey. Remarks:

None of the species of the genus Costasiella described until now have differently coloured median and outer cerata. The present new species differs from the preceding new species, $C$. paweli, in colour pattern and the absence of a mark on the neck, and is distinguishable from all other species of the genus in having unique colouration and striation of the cerata.

Living animals of this new species have a very peculiar manner of locomotion: they crawl in a jerky fashion, throwing their rhinophores forwards and backwards and so pulling their body along. It reminds one of the jumping movement of a rabbit and the species is thus named after the Japanese word for rabbit.

\section{Costasiella vegae sp. nov.}

(Fig. 6; Plate II, fig. 15)

Material examined: Ishigaki Island, between Uganzaki and Yarabuzaki, 0.5-1 $\mathrm{m}$ deep, on Avrainvillea erecta, 27/06/1991, 6 specimens.

Holotype: body length $5 \mathrm{~mm}$, sectioned and mounted on 8 slides, NHMW 85998. 


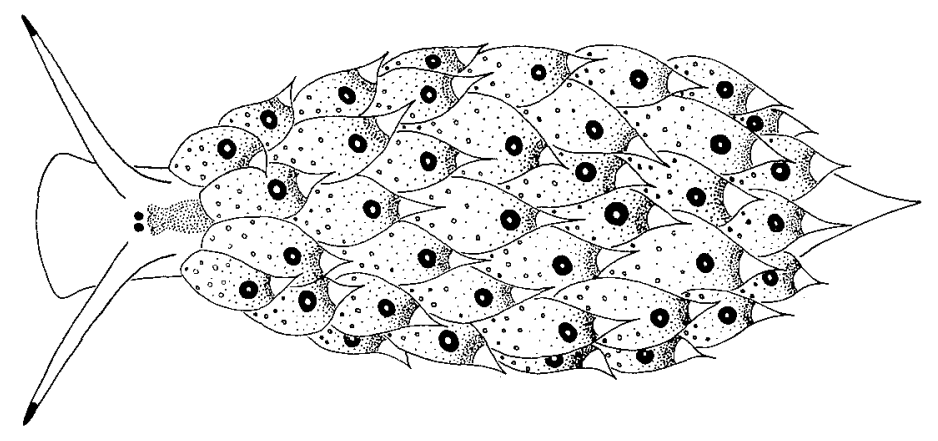

Fig. 6. Costasiella vegae sp. nov. Dorsal view.

Paratype: the other 5 specimens, deposited at the Seto Marine Biological Laboratory and in the author's collection.

Description:

Holotype.

The brown, contiguous eyes are situated between the bases of the rhinophores. The anterior corners of the foot are not extended. The rhinophores are white with black tips. The white head bears a conspicuous red mark behind the eyes like a posteriorly pointing arrowhead. The cerata are arranged in 8 rows and all are of the same colouration, green spotted with white dots. The distal portion of each ceras has many small red spots, whose density increases distally, eventually coalescing into a red line. The pointed tips of the cerata are white. On the dorso-distal part of each ceras is an eye-shaped pattern, a white spot encircled by a dark green circle. Paratype.

The size of the specimens ranged from 5 to $10 \mathrm{~mm}$ in body length. In one paratype specimen, just a red line is present on the head.

Remarks:

This species is remniscent of C. oculifera Clark, 1984, which occurs from Bermuda to Brazil, especially in colour. However, the latter has no eye-shaped pattern on the cerata. In both species, a conspicuous mark behind the eyes is present, but it differs in shape and colour between the two species. Moreover, $C$. vegae has more rows of serata.

Unlike both the preceding Costasiella species, the anterior corners of the foot do not protrude. Moreover, no eye-shaped pattern occurs on the cerata of the preceding species.

The specific name is based on the name of the brilliant star Vega in the constellation Lyra. 


\section{Costasiella rubrolineata sp. nov.}

(Fig.7)

Material examined: Ishigaki Island, between Uganzaki and Yarabuzaki, 0.5-1 m deep, on Avrainvillea erecta, 27/06/1991, 1 specimen.

Holotype: body length 4 mm, sectioned and mounted on 6 slides, NHMW 85999.

Description:

Holotype.

A black transverse band is present at the midlength of each rhinophore, and there is a rounded, dark red mark behind the eyes. Three red lines are located on the anterior part of the head, running from the bases of the rhinophores to the mouth area, and the middle line of the three is the broadest. The cerata are green with white, pointed tips, and an orange-red band is situated within the distal white area. Remarks:

The typical colouration of the anterior part of the head was not observed in the preceding species of this genus described above. The anterior corners of the foot are not protruded as they are in $C$. paweli and C. usagi. The eye-shaped pattern on the cerata, observed in C. vegae, is missing in this species.

The species is named for the characteristic red lines on the head.

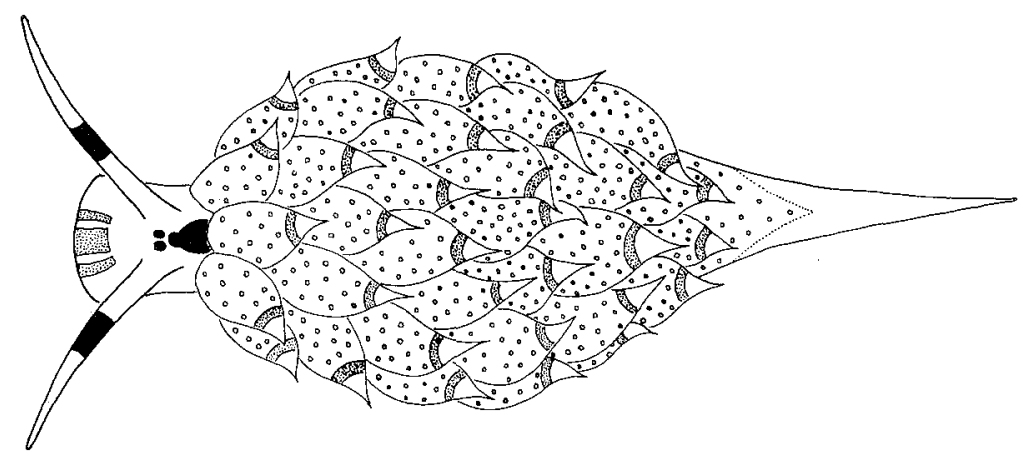

Fig. 7. Costasiella rubrolineata sp. nov. Dorsal view.

\section{Costasiella iridophora sp. nov.}

(Fig. 8; Plate II, fig. 16)

Material examined: Kuro Ialand, on Avrainville lacerata var, robustior A. \& E.S. Gepp, 01/07/1991, 1 specimen.

Holotype: body length $4 \mathrm{~mm}$, sectioned and mounted on 3 slides, NHMW 86000 .

Description: 


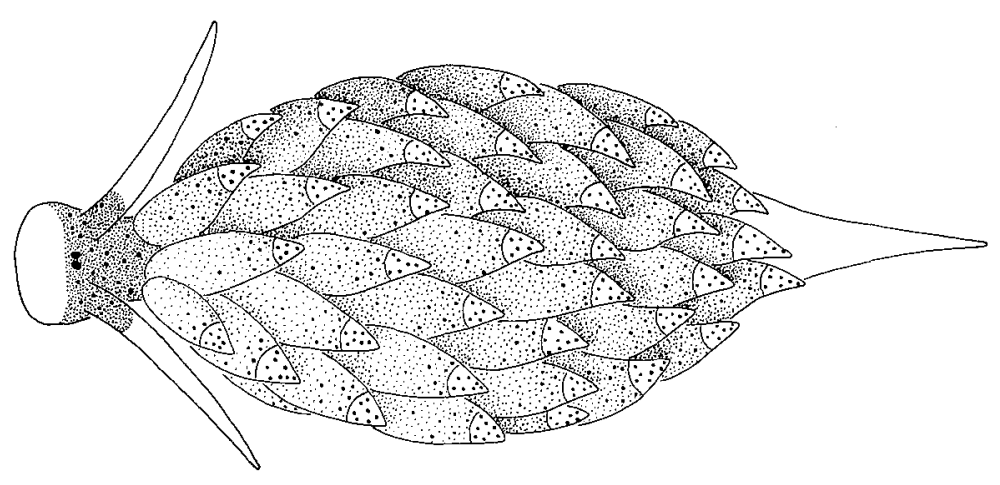

Fig. 8. Costasiella iridophora sp. nov. Dorsal view.

\section{Holotype.}

No oral tentacles are present. From the eyes backwards, including the bases of the rhinophores, the head is covered by small, iridescent, green dots. This colour pattern continues onto the cerata, which are arranged in 7-9 rows. The cerata are green with white tips which are dotted with many iridescent spots. The ventral foot is also fringed with such iridescent dots.

Remarks:

No species of Costasiella with a distinctive coloured area around the eyes have hitherto been described. Marcus \& Marcus (1969) reported for C. lilianae $(=C$. ocellifera) a whitish mask around the eyes and a diamond-shaped mark behind the eyes. In C. illa (Marcus, 1965) the head and the rhinophores seem to be unpigmented. C. virescens Prouvot-Fol, 1951 and C. pallida Jensen, 1983 have different colourations and sizes than all the herein described species. Moreover, in C. virescens the anterior corners of the foot are tentaculiform (Prouvot-Fol, 1954). The absence of the protruded anterior corners of the foot distinguishes this species easily from $C$. paweli and C. usagi.

The species is named after the iridescent dots which cover the dorsal surface.

\section{Costasiella kuroshimae sp. nov.}

(Fig. 9; Plate II, fig. 17)

Material examined: Kuro Island, on Avrainville lacerata var. robustior, 01/07/1991, 4 specimens.

Holotype: body length $4 \mathrm{~mm}$, sectioned and mounted on 4 slides, NHMW 86001.

Paratype: the other 3 specimens, deposited at the Seto Marine Biological Laboratory and in the author's collection.

Description:

The maximum body length of the 4 specimens was $4 \mathrm{~mm}$. 


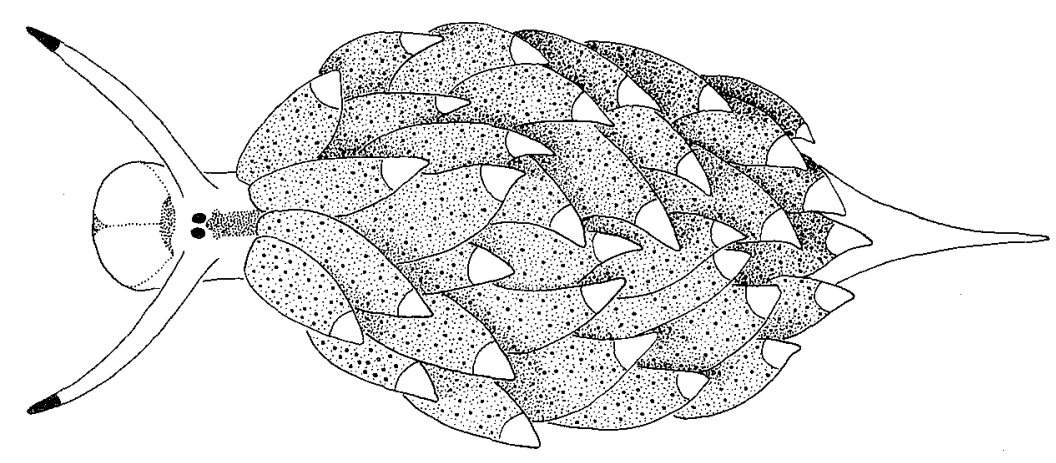

Fig. 9. Costasiella kurashimae sp. nov. Dorsal view.

Holotype.

The anterior part of the head is divided longitudinally by a brown colour pattern thus giving the impression of two roundish pouches. The rhinophores are white, but their tips are black. No oral tentacles are present. A brown mark is present medially behind the eyes. The cerata are arranged in 7 rows, generally green with white tips. Iridescent dots are scattered over the green parts of the cerata.

Remarks:

This new species is reminiscent in colouration of $C$. paweli, but the anterior corners of the foot do not protrude. Iridescent dots also occur in C. iridophora, but no such dots cover the head and neck region in the present species. The colour pattern of the anterior part of the head is unique in this genus.

The specific name is derived from the Japanese name of the island, where this species was found.

Family Elysiidae

Genus Elysiobranchus Prouvot-Fol, 1930

\section{Elysiobranchus ryukyuensis sp. nov.}

(Fig. 10; Plate II, fig. 18)

Material examined: Sesoko Island, among branches of Acropora sp., collected by Dr. Robert Kinzie III, 06/1991, 2 specimens.

Holotype: body length $4 \mathrm{~mm}$, NHMW 86002.

Paratype: 1 specimen, deposited in the author's collection.

Description:

Holotype.

The body is transparent but is covered with many white marks. The inner 


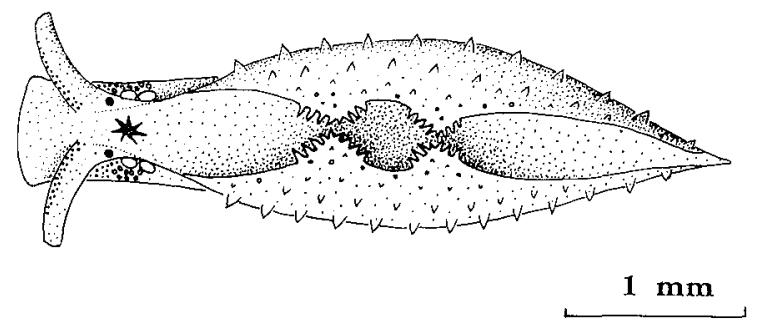

Fig. 10. Elysiobranchus ryukyuensis sp. nov. Dorsal view.

side of rhinophores and the area around the eyes are covered by many green dots, whereas the antero-lateral part of the foot is spotted with red dots. Two bigger, rounded, red marks are situated behind the eyes. A red, star-shaped mark is located beween the eyes. Single red and green spots are scattered over the parapodia, which also bear small, spiny, unpigmented papillae. The ventral side of the foot is covered with many opaque, white spots. The most conspicuous character, however, is the shape of the parapodia; the dorsal margin of each parapodium is extended into two erect, ramified appendages.

Remarks:

Prouvot-Fol (1930) established the genus Elysiobranchus by the following definition, "Expansions aliformes relevées et portantes sur leurs bords des processus dressés, ramifiés, au nombre de quatre paires", and amended in 1946 as "...les parpodies portent, au bord, quelques petits appendices dressés, ramifiés". The species considered herein bears two pairs of parapodial appendages, not four. However, such structures are not common within the Elysiidae, and therefore this new species is classified within the genus Elysiobranchus. The present species possibly resembles Elysiobranchus mercieri Prouvot-Fol, 1930 described and figured by Carlson \& Hoff (1978) from Guam. However, it is not sure that their species really is identical with Prouvot-Fol's species, because in the original description 4 pairs of branched processes, not 2 pairs, are described to be present. Since the original description of Elysiobranchus mercieri does not afford details, it is impossible to make a closer comparison.

The species was found in the coastal sea of an island close to Okinawa Island, the largest of the Ryukyu Islands, and the name of the islands is the basis of the specific name.

Genus Elysia Risso, 1818

\section{Elysia sugashimae Baba, 1955}

(No figure)

Material examined: Miyako Island, Oura Beach, 1-1.5 m deep, on Halimeda discoidea Decaisne, 23/06/1991, 1 specimen; Miyako Island, Oura Beach, 1-1.5 m deep, on Halimeda macroloba Decaisne, 24/06/1991; 
Ishigaki Island, between Uganzaki and Yarabuzaki, $0.5 \mathrm{~m}$ deep, 27/06/1991, 1 specimen; Kuro Island, 01/07/1991, 2 specimens; Iriomote Island, 04/07/1991, 4 specimens; Yonaguni Island, $06 / 07 / 1991,5$ specimens.

\section{Description:}

The body length ranged from 3 to $4 \mathrm{~mm}$. The body colour is grass-green, but the tips of rhinophores are white and between the parapodia the body is yellowish-green. The rhinophores are short and stout. The body shape is a characteristic long rectangle.

\section{Elysia kushimotoensis Baba, 1957}

(Fig, 11; Plate II, fig. 19)

Material examined: Kuro Island, Nakamoto Beach, on Caulerpa serrulata var, serrulata f, lata, 29/06/1991, 1 specimen; Kuro Island, near Kuroshima Marine Center, 30/06/1991, 2 specimens.

\section{Description:}

The body length ranged from 25 to $30 \mathrm{~mm}$. The body is smooth, without any papillae. Red spots are scattered over the head and the auriculate rhinophores and are clustered at the tips of the rhinophores, giving them a red appearance. The parapodia are wide with wavy margins, which continue posteriorly until the end of the body. The metapodial tip is rounded. The parapodial rim is dark red, and the outer surface of the parapodia is tinged green, with round, white spots and minute red dots. The lateral and ventral sides of the foot are orange or yellow. The inner sides of the parapodia looks like the outer sides, but an additional bright orange band runs parallel to the dark red margin on the inner side. No black spots are present on any part of the body.

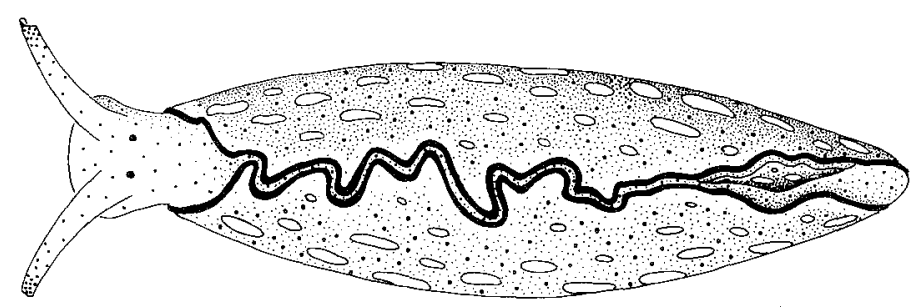

Fig. 11. Elysia kushimotoensis Baba, 1957. Dorsal view.

\section{Elysia flavipunctata sp. nov.}

(Plate II, fig. 20)

Material examined: Ishigaki Island, Yonehara, on Halimeda discoidea, Halimeda macroloba and Halimeda opuntia f. cordata Barton, 16/06/1991, 7 specimens. 
Holotype: body length $5 \mathrm{~mm}$, NHMW 86003 .

Paratype: all the remaining 6 specimens, deposited at the Seto Marine Biological Laboratory and in the author's collection.

Description:

Holotype.

The body colour is dark green. The margins of the parapodia are either white or dotted white. The lateral part of the foot is covered with white spots, whereas the sole of the foot is transparent. The whole body is moreover covered with minute, yellow dots, which are concentrated in a yellow area on the dorsal side of the head and in three characteristic big yellow marks along the anterior, median and posterior outer and inner parapodial margins. The parapodia touch each other at the yellow marks and thus form funnels. The long, tapering rhinophores are unpigmented except for three transverse, dark green stripes or dotted lines.

Paratype.

The body length ranged from 4 to $6 \mathrm{~mm}$. The body colour is dark or light green.

Remarks:

Smaller or larger light spots are common in many species of Elysia. The present species resembles E. yaeyamana Baba, 1936 in colour, but it differs in size and the presence of the three yellow marks and transverse stripes on the rhinophores. $E$. tokarensis Baba, 1936 is distinguished from the present new species and E. yaeyamana by the presence of black spots on the parapodia and by the black tips of rhinophores.

Jensen (1983) reported specimens of E. atroviridis Baba, 1955 from Hong Kong that bear two light patches located some distance apart along the inner side of the parapodial margins and a yellow patch on the head, formed of numerous small, yellow dots. She called the parapodial light patches "glandular patches" and noted that they were "associated with the 'funnels' formed when the parapodia are held together dorsally". The same feature was observed in the present species. The rhinophores of $E$. atroviridis differ in shape and colour from those of the present new species.

The specific name is coined after the colour of the characteristic yellow marks.

\section{Elysia minima sp. nov.}

(Fig. 12; Plate II, fig. 21)

Material examined: Kuro Island, Nakamoto Beach, 29/06/1991, 1 specimen; Kuro Island, near the Kuroshima Marine Center, 02/07/1991, 1 specimen.

Holotype: body length $3 \mathrm{~mm}$, collected on $02 / 07 / 1991$, sectioned and mounted on 3 slides, NHMW 86004 .

Description:

Holotype.

The general body colouration is yellowish-green. The area between the mouth and the rhinophores and the inner sides of the rhinophores are black or dark 


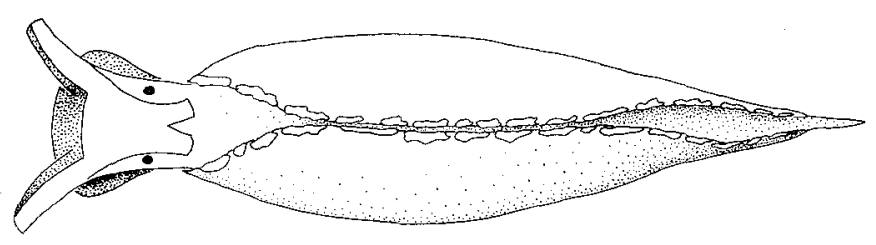

Fig. 12. Elysia minima sp. nov. Dorsal view.

blue, whereas the rest of the head and other parts of the rhinophores are covered by a thick, white crust that forms a cross-shaped figure. The triangular parapodia are small and their margins are also partially coated with a white crust. No dorsal vessels are visible.

Remarks:

The characteristic white, cross-shaped mark on the head and the white patches on the parapodial margin are also present in E. tuca Marcus, 1967 (Marcus \& Hughes, 1974). Moreover, the inner side of the rhinophores are also dark in that species. Unlike E. tuca, no papillae, black spots and black metapodial margin are present in the present new species. The most characteristic feature of $E$. tuca is recorded to be the branching of the dorsal vessels. This feature has only been recorded in E. chitwa Marcus, 1955, besides E. tuca. In the present species the dorsal vessels are invisible. The dorsal surface of the body of $E$. chitwa is covered with red dots, which are not present in the present new species. In all these three species, there is black pigment between the rhinophores. Since $E$. chitwa occurs on the coast of Sao Paulo, Brazil, and E. tuca in the Caribbean Sea, and because the colouration. is different as stated above, the present new species is proposed.

The species is named for its small size.

\section{Acknowledgements}

I am most grateful to Prof. Dr. E. Harada and all the staff of the Seto Marine Biological Laboratory for providing laboratory space and help. Special thanks are due to all members of the Sesoko Marine Science Center, the Kuroshima Marine Center and the Akajima Marine Science Laboratory for the use of laboratory facilities. In addition, I wish to express my heartiest thanks to Mr. P. Slawatycki for his invaluable assistance in many aspects of this research. I would like to thank Prof. Dr. K. Baba and Dr. M.J. Grygier for critically reading the manuscript. This research was carried out while bolding a fellowship-grant from the Japanese Foreign Ministry under the auspices of the Special Exchange Program (SAP) administered through the Japanese-German Center in Berlin.

\section{References}

Baba, K. 1936. Opisthobranchia of the Ryukyu (Okinawa) Islands. Journ. Dept. Agric., Kyushu Imp. Univ., 5: 1-50, pls. 1-3.

-1949. Opisthobranchia of Sagami Bay collected by His Majesty The Emperor of Japan. Iwanami Shoten, Tokyo. $4+194+7$ pp., Pls. I-L. (Japanese and English parts)

1955. Opisthobranchia of Sagami Bay, Supplement. Collected by His Majesty The Emperor of Japan. Iwanami Shoten, Tokyo. $3+59$ pp., Pls. I-XX. (Japanese and English parts) 
1957. The species of the genus Elysia from Japan. Publ. Seto Mar. Biol. Lab., 6(1): 69-74 1959. The family Stiligeridae from Japan. Ibid., 7(3): 327-334.

1966. Gross anatomy of the specimens of the shelled saccoglossan Volvatella (=Arthessa) collected from Okino-Erabu Island, Southern Kyushu, Japan. Ibid., 14(3): 197-205.

Bergh, R. 1905. Die Opisthobranchiata der Siboga-Expedition. Siboga-Expeditie, Monograph 50, 1-248, Taf. I-XX.

Burn, R. 1966. The opisthobranchs of a caulerpan microfauna from Fiji. Proc. Malac. Soc. London, 37: $45-65$.

Carlson, C.H. \& Hoff, P.J. 1978. Identifiable Elysia from Guam (Elysiidae, Saccoglossa, Opisthobranchia). Micronesica, 14(1): 89-113.

Clark, K.B. 1982. A new Volvatella from Bermuda, with comments on the genus. Bull. Mar. Sci., 32(1): $112-120$

- 1984. New records and synonymies of Bermuda opisthobranchs. Nautilus, 98(2): $85-97$.

Habe, T. 1946. On some species of the Cephalaspidea from Japan. Venus, 14(5-8): 183-190. (in Japanese)

Hamatani, I. 1969. A new species of the rare shelled sacoglossan genus Cylindrobulla from middle Japan. Publ. Seto Mar. Biol. Lab., 17(3): 171-174.

-1972. A new specise of Volvatella Pease, 1860, found in the "caulerpan microfauna" in the province of Kii, middle Japan. Ibid., 21(1): 13-20.

- 1976. Prcliminary account of a new species of Volvatella Pease, 1860, V. viridis sp. nov., found in the caulerpan microfauna in Japan, Ibid., 22(6): 371-376.

- 1980. On the species of the genus Oxynoe Rafinesque, 1819, from Japan, inclusive of a new species. Ibid., 25(5/6): 349-360.

Jensen, K.R. 1983. Annotated checklist of Hong Kong Ascoglossa, with descriptions of four new species. Proc. 2nd Int. Workshop on the Malacofauna of Hong Kong and Southern China: 77-107.

Kawaguti, S. 1981. A new bivalved gastropod, Julia zebra n. sp. Bull. Kawasaki Para Medical College, 1: $9-13$.

_ \& Baba, K. 1959. A preliminary note on a two-valved sacoglossan gastropod, Tamanozalva limax, n. gen., n. sp., from Tamano, Japan. Biol. Journ. Okayama Univ., 5: 177-184.

____ \& Yamasu, T. 1982. A new bivalved gastropod, Julia mishimaensie n. sp. Proc. Japan. Acad., $58(B)(2): 29-31$.

Kay, E.A. 1961. A new opisthobranch mollusc from Hawaii. Pac. Sci., 15(1): 112-113.

Kitao, K. 1976. The sacoglossa from Caulerpa in Kabira Bay of Ishigaki Island. The Nanki Seibutu, 18(2): 49-53. (in Japanese)

1977. The sacoglossa from Ishigaki Island. Ibid., 19(2): 64-68. (in Japanese)

. 1978. Nottes on Julia from Ishigaki Island. Ibid., 20(2): 75-77. (in Japanese)

Marcus, E. 1965. Some Opisthobranchia from Micronesia. Malacologia, 3(2): 263-286.

Marcus, E.d.B.-R. 1972. On some opisthobranchs from Florida. Bull. Mar. Sci., 22(2): 284-308.

1980. Review of western Atlantic Elysiidae with description of a new Elysia species. Ibid., 30(1): 54-79.

\& Hughes, H.I.P. 1974. Opisthobranch mollusks from Barbados. Ibid,, 24(3): 488-532.
\& Marcus, E. 1960. Opisthobranchs from American Atlantic warm waters. Bull. Mar. Sci. Gulf \& Carib., 10(2): 129-203.

Prouvot-Fol, A. 1930. Diagnoses provisoires des Mollusques Nudibranches en Nouvelle Calédonie. Bull. Mus. Hist. Nat. Paris, 2(2): 229-231.

- 1946. Révision critique de la familie des Elysidae. J. Conchyl., 87(1): 29-44.

-1954. Mollusques opisthobranches (Monostichoglosses). Faune de France, 58: 170-205.

Thompson, T.E. 1973. Sacoglossan gastropod molluscs from Eastern Australia. Proc. Malac. Soc. London, 40: 239-251.

—_. 1977. Jamaican opisthobranch molluscs I. J. Moll. Stud., 43: 93-140.

Toma, T. 1990. An observation of Cyerce sp. from Miyako Island in the Ryukyu Islands. Biol. Mag. Okinawa, 28: 55-57. (in Japanese)

Ui, S. \& Umezaki, N. 1988. Sea algae and coastal plants. Okinawa Kaichu Seibutsu Zukan, Vol. 6, Shinsei Tosho Shuppan, Naha. 239 pp. (in Japanese) 


\section{EXPLANATION OF PLATES I-II}

Plate I

Fig. 1. Volvatella viridis Hamatani, 1976.

Figs. 2 \& $3 . \quad$ Volvatella angeliniana sp. nov.

Fig. 4. Volvatella sp.

Fig. 5. Ascobulla japonica (Hamatani, 1969).

Figs. 6 \& 7. Lobiger souverbii Fischer, 1856. Fig. 7 shows a small individual Figs. 8a-c. Oxynoe viridis (Pease, 1861). The specimens of different colouration types are shown. a: body colouration (1) from Nakamoto Beach; b: body colouration (2) from Kuro Island; c: body colouration (3) from Agonohama.

Plate II

Fig. 8d. Oxynoe viridis (Pease, 1861). d: body colouration (4) from Majanohama.

Fig. 9. Tamanovalva limax Kawaguti \& Baba, 1959.

Fig. 10. Hermaea dendritica (Alder \& Hancock, 1843)

Fig. 11. Aplysiopsis wrangeliae sp. nov.

Fig. 12. Ercolania smaragdina Baba, 1949.

Fig. 13. Costasiella paweli sp. nov.

Fig. 14. Costasiella usagi sp. nov.

Fig. 15. Costasiella vegae sp. nov.

Fig. 16. Costasiella iridophora sp. nov.

Fig. 17. Coslasiella kuroshimae sp. nov.

Fig. 18. Elysiobranchus ryukyuensis sp. nov.

Fig. 19. Elysia kushimotoensis sp. nov.

Fig. 20. Elysia flavipunctata sp. nov.

Fig. 21. Elysia minima sp. nov. 
Publ. Seto Mar. Biol. Lab., 36(3/4). 1993.

PLATE II
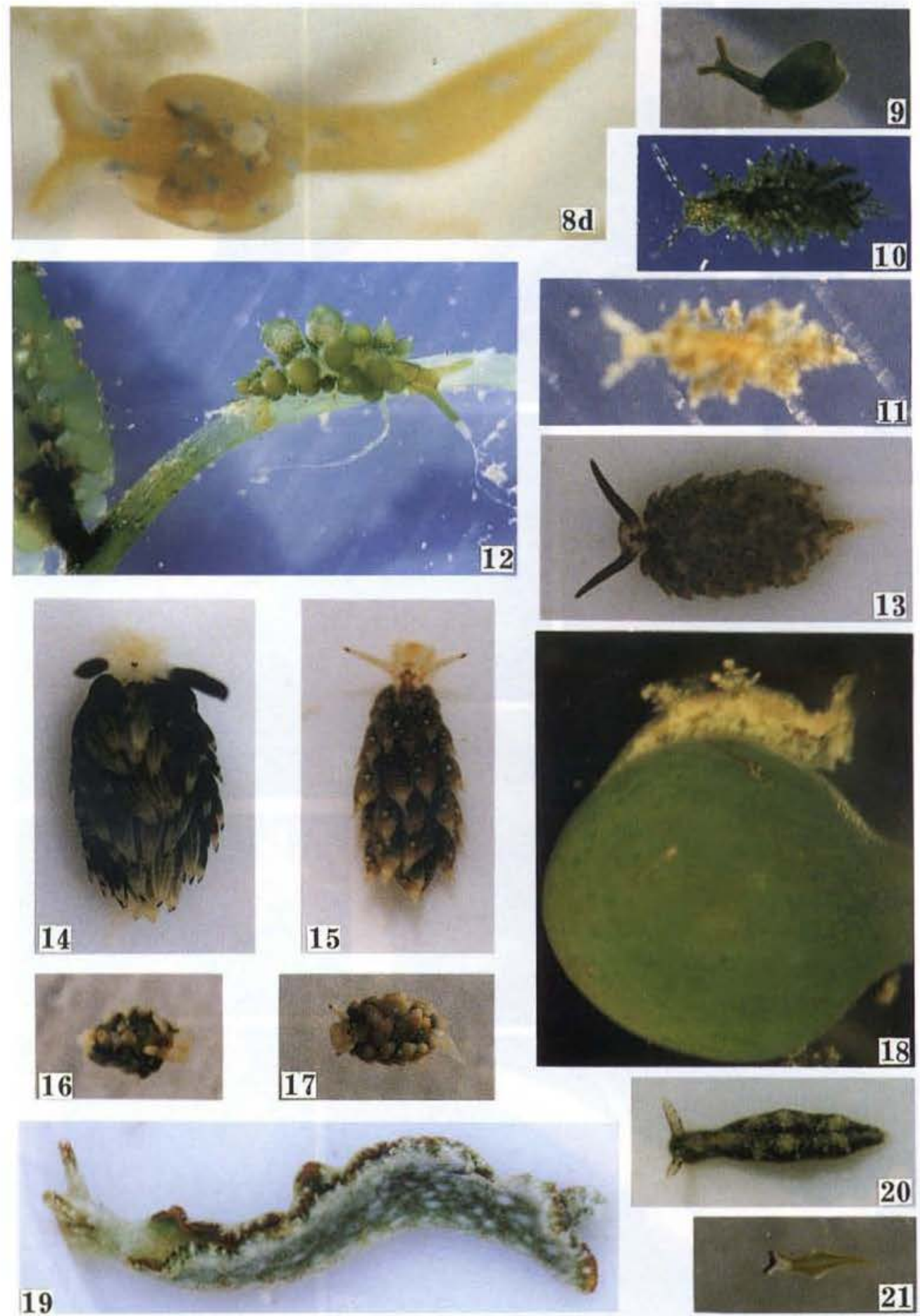

M. IchiкAWA: Saccoglossa from Ryukyu 
Publ. Seto Mar. Biol. Lab., 36(3/4), 1993.

PLATE I
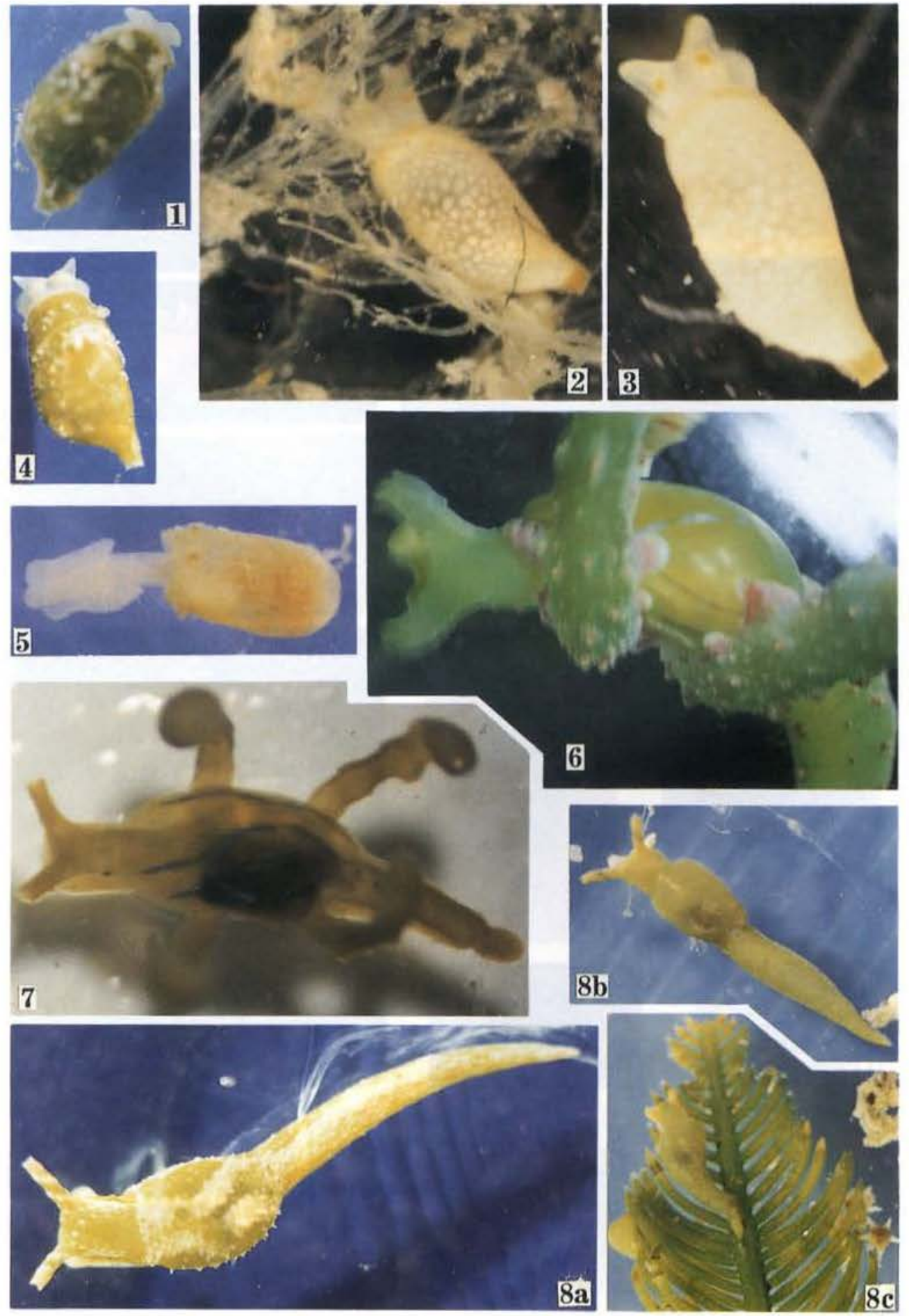

M. Ichikawa: Saccoglossa from Ryukyu 